Article

\title{
How Proactive Environmental Strategy Facilitates Environmental Reputation: Roles of Green Human Resource Management and Discretionary Slack
}

\author{
Jinguo Zhao ${ }^{1}$, Huanxin Liu ${ }^{2}$ and Wei Sun ${ }^{2, *}$ \\ 1 School of Management, Qilu University of Technology (Shandong Academy of Sciences), Jinan 250353, \\ China; zhaojinguo@qlu.edu.cn \\ 2 School of Management, Shandong University, Jinan, 250100, China; huanxinsdu@163.com \\ * Correspondence: sunwei_sdj@163.com
}

Received: 23 December 2019; Accepted: 18 January 2020; Published: 21 January 2020

check for updates

\begin{abstract}
Based on natural resource-based theory, we examined how firms' environmental strategies and environmental reputation depended on their green human resource management and discretionary slack. From the perspective of human resource management, we hypothesized that proactive environmental strategy predicted firms' environmental reputation through the mediation of green human resource management. We further proposed that slack resources, which can be used discretely by managers for environmental management, enhanced the hypothesized relationships. Using data from firms in environmentally sensitive industries in eastern China, we provided empirical support for our hypotheses. The findings highlight the vital roles played by managers and green human resource management in implementing firms' environmental strategies and promoting firms' environmental reputation.
\end{abstract}

Keywords: proactive environmental strategy; environmental reputation; green human resource management; discretionary slack; resource-based theory

\section{Introduction}

Environmental reputation is the level of environmental credibility ascribed to a firm by its stakeholders, representing perceived levels of past and possible future environmental performance relative to those of other participants in the same industry [1,2]. Nowadays, many firms face increasing regulatory and social pressure to enhance their environmental management, and they must respond appropriately to the external pressure, particularly when operating in environmentally sensitive sectors [3,4]. So, a good environmental image is a useful way of enhancing a firm's competitiveness when society demands a cleaner environment $[5,6]$. Under this circumstance, a growing number of firms have developed proactive environmental strategies to guide their environmental management practices [7].

According to the natural resource-based view (NRBV), a firm's competitive strategies and its performance rely significantly on the firm's specific organizational resources and capabilities [8-11]. From this perspective, research on proactive environmental strategy indicates that proactive environmental strategy can benefit firms a lot and help firms gain competitive advantages, such as enhancing their image [12], financial performance [13], environmental performance [14] and eco-innovation [15]. Previous research mainly focused on the important roles a firm's resources—such as environmental investments, environmental collaboration with suppliers, and organizational green climate-play in the relationship between proactive environmental strategy and its environmental outcomes. However, although the engagement of leaders and employees is fairly necessary to the 
implementation of firms' strategies, few studies have taken human resources into consideration, especially from a systematic perspective [16].

Green human resource management (GHRM), which was defined by Ren, Tang, and Jackson [17], (2018:778) as "phenomena relevant to understanding relationships between organizational activities that impact the natural environment and the design, evolution, implementation, and influence of HRM systems", provides a new opportunity to investigate the effects of proactive environmental strategy and its outcomes on firms. GHRM is a set of practices to implement the strategy of a firm toward environmental protection, which can be regarded as a competitive capability to encourage employees to engage in pro-environmental activities within the firm. Therefore, it is important to explore how proactive environmental strategies help firms develop capabilities concerning human resources and ultimately improve firms' environmental reputation [18].

In addition, GHRM incurs some uncertainty or risk, because its long-term effects take time to become evident $[19,20]$. It is therefore important for corporate managers, who are mainly responsible for the operation of firms, to have some resources that can be deployed in the form of discretionary slack, particularly the time and resources required for managers' creative problem-solving at the interface between the natural environment and business management $[9,21]$. Thus, those leaders who have available discretionary slack for environmental management are more capable of supporting the implementation of environmental strategy than those who do not have it.

Therefore, the primary objectives of this study are to explore the roles that GHRM and discretionary slack for environmental issues play in the relationship between proactive environmental strategy and environmental reputation. We investigate the direct influence of proactive environmental strategy on GHRM. Furthermore, we argue that a firm's GHRM has positive effects on its environmental reputation, and GHRM represents its prioritization of HRM in environmental management and plays an important mediating role in helping the firm to implement its environmental strategy and improve its environmental reputation $[19,20]$. Finally, we examine the influence of the interaction between proactive environmental strategy and discretionary slack on GHRM practices (see Figure 1). By offering a richer explanation and empirical assessment of the processes linking environmental strategy, GHRM, discretionary slack for environmental issues, and environmental reputation, we provide a greater understanding of how a firm's competitive strategies and reputation for the environment depend on its green human resources and discretionary resources, which enriches NRBV.

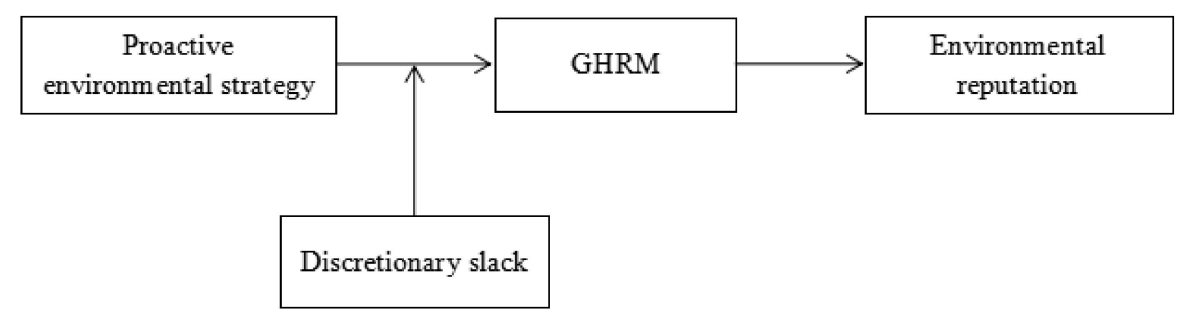

Figure 1. Research model.

\section{Literature Review and Hypotheses}

\subsection{Proactive Environmental Strategy and GHRM}

Environmental strategy refers to the managerial interface between a firm's development and the natural environment [22]. A proactive environmental strategy includes a series of environmental visions, goals, plans, and processes that are good for the natural environment [14]. According to the NRBV, the proactive environmental strategy of a firm reflects its ability to efficiently leverage its tangible and intangible resources, contributing to increasing a firm's competitive advantages $[7,16]$. So, firms with proactive environmental strategies tend to voluntarily invest resources to achieve their goals [11]. A growing number of researchers have demonstrated that the process of implementation of strategy affects whether a well-developed strategy can achieve its goal $[23,24]$. Therefore, competitive 
approaches are essential for firms to implement their environmental strategies and achieve their goals [8].

Environmental management is a human resource-intensive process, so how to motivate employees to engage in this process is essential to achieve firms' environmental performance [25]. Thus, human factors are quite necessary for the implementation of strategies and plans within a firm. GHRM can be classified as ability-oriented GHRM practices, motivation-oriented GHRM practices, and opportunity-oriented GHRM practices [26,27], and it tends to improve employees' pro-environmental ability, inspire their pro-environmental motivation, and provide them with opportunities to engage in. This process is highly important to improve a firm's environmental performance and reputation, and thus help the firm to cultivate environmental competitiveness [28]. Therefore, GHRM can be seen as a key approach for a firm to motivate its employees to engage in pro-environmental activities, as well as an efficient resource to support the firm's environmental strategy [20]. So, firms which put an emphasis on green human resources can accumulate the progress of implementing environmental strategies, solving environmental problems, and enhancing their environmental reputation [29]. Therefore, firms with proactive environmental strategies and a desire to gain green competitiveness tend to take GHRM as an efficient approach. Based on the above arguments, we propose that:

\section{H1. Proactive environmental strategy is positively related to GHRM.}

\subsection{GHRM and Environmental Reputation}

GHRM reflects the ways in which firms develop their environmental strategies and actions to gain a green image using a bundle of HR practices. According to NRBV, GHRM can be regarded as an efficient approach to help firms translate their strategies into environmental performance or competitive advantages for the environment $[16,19,20]$. Specifically, GHRM includes green recruitment and selection, green training, green performance management, green pay and rewards, and green involvement. The processes of green recruitment and selection include green employer branding, using green criteria to attract candidates, and checking candidates' green awareness [20]. Firms may use professional assistance to design a series of tests and green criteria to select candidates whose work will be of environmental value. Employees with green awareness have been shown to strengthen their environmental skills in their work, which in turn augments their environmental performance, gradually cultivates a green employer brand, and enhances firms' environmental reputation [30].

Green training emphasizes various programs designed to increase employees' green awareness and environmental knowledge and skills, and the green atmosphere of the whole firm [20]. To implement green training activities, firms must design scientific green training systems and pay for training. Green training activities can develop and increase employees' capability for environmental protection. Activities can also form a virtuous cycle, where employees with good environmental abilities have a greater incentive to engage in actions that can further enhance their own environmental skills. These training programs greatly enhance the participation of employees in environmental activities, which in turn promotes the implementation of a corporate environmental strategy and creates an environmentally friendly public image for the firm [31].

Green performance management means firms set green goals for employees, design green performance indicators, evaluate green performance, and implement relevant dis-benefits [32]. Establishing targets for employees can help employees clearly understand their green tasks. Using normative evaluation criteria to measure employees' green performance can not only motivate employees to meet their targets, but also make them feel more responsible for their environmental actions. Implementing dis-benefits warns employees who may be punished if their efficiency is too low [20].

Green pay and reward requires firms to provide financial rewards such as green travel benefits, and non-financial rewards such as recognition and praise. Although it can be expensive, the combination 
of financial and non-financial rewards is the most efficient way to mobilize the green enthusiasm of employees, which ultimately contributes to the development of green firms [32].

Green involvement means firms provide opportunities for employees to participate in environmental management. For instance, firms may encourage the development of formal and informal communication platforms to enable employees to fully express their opinions and feedback on environmental protection. Although firms may incur some losses as a result of green involvement (for example, employees' excessive attention to environmental issues may reduce their job output) [20], the relaxed and supportive atmosphere fostered by this strategy can inspire employees to acquire more green knowledge and make them more willing to engage in green activities. In addition, soliciting green advice from employees makes them more responsible and mission-oriented, which not only helps to improve the effectiveness of the firm's environmental management, but also helps the firm establish a good environmental reputation [20,32-34]. Accordingly, we propose that:

H2. GHRM is positively related to environmental reputation.

\subsection{Mediating Role of GHRM}

According to NRBV, we can draw some conclusions from the overall process of implementing GHRM. First, firms with proactive environmental strategies are capable of using their resources efficiently, and they tend to construct specific GHRM practices, because GHRM is an efficient and necessary approach to implement environmental strategies. Second, GHRM can enhance employees' green skills, knowledge, and abilities. The green human capital acquired by firms is the central driver of environmental performance, which helps firms to gain a good reputation and ensure their sustainable growth in the long run. So, the availability of human resources due to GHRM can be seen as a capability for a firm to implement environmental strategy, which plays an important role in enhancing environmental reputation. Thus, we hypothesize as follows:

H3. GHRM mediates the positive relationship between proactive environmental strategy and environmental reputation.

\subsection{Moderating Effect of Discretionary Slack}

GHRM requires investment from firms and is indispensable to the overall effectiveness of environmental management [35]. However, it remains unclear how long it takes for GHRM to positively affect firms' environmental performance and reputation. Some risks and uncertainties may lead managers to question whether it is worthwhile to use the existing financial, human, and other resources of the firm to invest in GHRM $[17,36]$. Discretionary slack resources can release capital restrictions and enhance managers' strategic choices in environmental management, which increases flexibility, opportunity orientation, and risk taking [9,37].

Slack is a type of resource that enables firms to implement their strategies. Firms' expenditure and initiatives may be sensitive to slack resources [38]. Cultivating green human capital is expensive and involves experimentation and risk-taking. Firms can implement GHRM more efficiently if some discretionary slack is available to help managers carry out environmental activities. First, the use of slack for green initiatives at managers' discretion helps to reduce intra-organizational conflicts over resources and supplements that are invested formally in GHRM to support the environmental strategy [21]. This investment enables managers to be more confident about the development and implementation of environmental strategy via GHRM, which in turn can enhance the efficiency of using resources and cultivating human capital [9]. Discretionary slack is also associated with managerial interpretation. In other words, leading managers may decide to use discretionary slack for environmental management, indicating that they regard this as an investment opportunity and lay a great emphasis on environmental protection [9]. Under these circumstances, GHRM is better equipped to absorb other resources of firms and mobilize employees' environmental enthusiasm [39]. On this basis, we hypothesize as follows: 
H4. The positive relationship between proactive environmental strategy and GHRM is stronger when discretionary slack is greater.

\section{Research Method}

\subsection{Sample and Procedure}

Data were collected in high-polluting industries (mainly small-to-medium-sized firms in eastern China), such as chemical, metal, and biomedical industries, because these firms operate in more environmentally sensitive sectors and may face more environmental problems. In order to pursue profitability and sustainable growth, it is very important for them to have a good environmental reputation. Thus, it is meaningful to investigate how firms in high-polluting industries develop an environmentally friendly image based on their proactive environmental strategies. We used a questionnaire survey to examine the relationships between proactive environmental strategy, discretionary slack, GHRM, and environmental reputation. The questionnaires were randomly mailed to our target firms using postage-paid envelopes. All participants were informed that participation was voluntary and that their responses were confidential.

Participants in this study were the Chief Human Resources Officers (CHO), Chief Financial Officers (CFO), Chief Executive Officers (CEO), and employees of 121 environmentally sensitive firms (chemical, metal, and biomedical firms, and so on) in eastern China. To reduce the common method biases [40], we used the multi-source and multi-time method to collect the questionnaires. Specifically, in the first wave (T1), with the help of local government agencies and research assistants in one technical university, we mailed the questionnaires about financial performance, discretionary slack and environmental strategy to the 200 targeted firms. The CFOs provided their demographic information and ratings to assess the financial performance and discretionary slack, and the CEOs rated the environmental strategies of their firm. Eight months later, in the second wave (T2), we invited the research assistants to distribute the second survey to the 170 firms which had returned their surveys at Time 1. At this time, the CHOs in these firms were asked to rate their firms' GHRM. Then, one month later, in the third wave (T3), we sent the third survey to the 149 firms which had returned their questionnaires at Time 2. With the help of the CHOs, local agencies, and research assistants, we distributed the questionnaires to employees (each firm chose at least five employees to answer the questionnaires) of the 149 firms to evaluate their firms' environmental reputation. After cleaning the data and excluding missing cases, the final sample consisted of 121 firms (matched CEOs, CFOs, and CHOs) and 583 employees' questionnaires, with a total response rate of $60.5 \%$ (121/200). Of the total $121 \mathrm{CFOs}$, (CHOs, CEOs), 71.4\% (77.3\%, 90.9\%) had a bachelor's degree, and the mean age was 39.7 $(38.3,44.0)$ years. Of the employees, $56.6 \%$ had a bachelor's degree, and the mean age was 33.5 years.

\subsection{Measures}

The questionnaires were first developed in English. Given that the Chinese respondents varied in their ability to comprehend English, a professional translation service translated all items into Chinese following a back-translation strategy [41]. The questionnaire was reviewed by a group of employees in a local manufacturing firm to pretest the suitability of the design and wording of the questionnaire. All responses were made using a five-point Likert-scale $(1=$ "strongly disagree" and $5=$ "strongly agree") unless indicated otherwise, and responses with higher scores represented greater standing on the variable of interest.

Proactive environmental strategy: proactive environmental strategy was rated by CEOs using eight items selectively adapted from Sharma (2000) [9]. Sample items included: "Our firm focuses on reducing fossil fuel use", "Our firm focuses on using clean energy". The composite reliability was 0.943 and the Cronbach's alpha was 0.944 (see Table 1). 
Table 1. Reliability and validity of the constructs.

\begin{tabular}{|c|c|c|c|c|c|c|c|c|}
\hline \multirow[b]{2}{*}{ Construct } & \multirow[t]{2}{*}{ Cronbach's $\alpha$} & \multirow[t]{2}{*}{$\begin{array}{l}\text { Factor } \\
\text { Loading }\end{array}$} & \multirow[t]{2}{*}{$\begin{array}{c}\text { Composite } \\
\text { Reliability (CR) }\end{array}$} & \multirow[t]{2}{*}{$\begin{array}{l}\text { Convergence } \\
\text { Validity (AVE) }\end{array}$} & \multicolumn{4}{|c|}{ Discriminant Validity } \\
\hline & & & & & PES & GHRM & DS & ER \\
\hline PES & 0.944 & $0.764 \sim 860$ & 0.943 & 0.674 & 0.821 & & & \\
\hline GHRM & 0.962 & $0.899 \sim 969$ & 0.970 & 0.866 & 0.223 & 0.931 & & \\
\hline DS & 0.827 & $0.799 \sim 890$ & 0.834 & 0.715 & 0.353 & 0.462 & 0.846 & \\
\hline ER & 0.916 & 0.879 962 & 0.918 & 0.849 & 0.435 & 0.325 & 0.361 & 0.921 \\
\hline
\end{tabular}

Notes: $\mathrm{n}=121$; PES is proactive environmental strategy; GHRM is green human resource management; DS is discretionary slack; ER is environmental reputation. Bold italic is the square root of the AVE.

GHRM: green human resource management was rated by $\mathrm{CHOs}$ using 18 items developed by Tang et al. (2018) [20] on green recruitment and selection, green training, green performance management, green compensation, and green involvement. Sample items included: "We use green performance indicators in our performance management system and appraisals" and "We develop training programs in environmental management to increase environmental awareness, skills, and expertise". The composite reliability was 0.970 and the Cronbach's alpha was 0.962 (see Table 1).

Discretionary slack (mainly in the environmental direction): discretionary slack was developed by Sharma (2000) [9]. It was rated by CFOs and sample items included: "Top managers in our firm have much discretion in the investment of resources for environmental decisions" and "Top managers in our firm have much discretion in the modification of practices for reducing environmental impact". The composite reliability was 0.834 and the Cronbach's alpha was 0.827 (see Table 1).

Environmental reputation: due to the special role employees played in the mutual relationship with firms, environmental reputation was rated by the nominated employees using two items developed by Backhaus and Tikoo (2004) [42]. Employees' perceived environmental reputation is important. Although research about firm reputation has mainly focused on its definition, basic meaning, and measurement from the perspective of general external stakeholders (e.g., general public and consumers), little attention has been paid to the staff perspective in firm reputation research $[43,44]$. Employees are a type of special stakeholder in firms, and there is a mutual relationship between employees and the firm. Firm reputation has a positive effect on the attitudes and motivation of employees in the workplace by affecting their recognition and identification of the firm. In turn, such perception and identification of firm reputation can inspire employees to make more effort on the initiatives which aim to enhance firm reputation. It can also make employees more willing to spread the "good reputation" message to consumers and other external stakeholders, which ultimately affects firm reputation [45]. Therefore, we adopted this method to measure environmental reputation.

The items included: "Our company's record on environmental protection is better than other organizations in our industry sector" and "We are recognized as an environmentally friendly company". We evaluated these two items at the individual employee level, and checked the aggregation statistics to identify if there was meaningful agreement among employees from the same firm and also the between-firm variance. We calculated intraclass correlations-ICC(1) and ICC(2) and $r_{\mathrm{wg}}$. The ICC(1) value for environmental reputation was 0.508 , the ICC(2) value was 0.851 , the $r_{\mathrm{wg}}$ value was 0.919 , $\mathrm{F}(120,461)=6.712, p<0.01$, which supported aggregating this variable at the firm level. The composite reliability was 0.918 and the Cronbach's alpha was 0.916 (see Table 1).

Control variables: in our sensitivity analysis described at the end of the results section, some additional variables were added to test the robustness of findings to the possibility of spurious association. We controlled firms' financial performance, because investment in environmental practices needs financial resources, thus financial status may affect firms' investment in green human resource practices [5]. Financial performance used seven items, developed by Li and Atuahene-Gima (2001) [23]. Because many targeted manufacturing firms are not publicly listed, we adapted the questionnaire. Financial performance was rated by CFOs and sample items included: "The total sales volume of our firm is large", "The total sales growth rate is high in our firm", and "The level of profit in our firm is 
high". The composite reliability was 0.878 and the Cronbach's alpha was 0.898 . We also controlled the ownership of our target firms (state-owned, private, and foreign enterprises were coded 1-3) [46,47].

\subsection{Data Analyses}

We used the SPSS macro process to test our hypotheses in two interlinked steps. First, we chose Model 4 to examine the mediation model (Hypotheses 1, 2, and 3). Then, we used a moderator model (Model 1) to test the moderated effect (Hypothesis 4). Prior to the moderating analyses, all continuous measures were mean-centered [48].

\subsubsection{The Analytic Method of Mediation}

Collectively, Hypothesis 1 suggested a simple regression between proactive environmental strategy and GHRM, Hypothesis 2 suggested a positive relationship between GHRM and environmental reputation, and Hypothesis 3 indicated a mediating effect of GHRM on proactive environmental strategy and environmental reputation. The multi-step approach proposed by Baron and Kenny (1986) [49] has always been used to guide such mediation hypothesis tests. Recently, however, some potential shortcomings have been identified in this approach [50], and methodologists have questioned whether it is necessary to illustrate that the initial variable is correlated with the outcome [51]. Consequently, it is recommended that mediation analyses should be based on formal significance tests of the indirect effect $a b$, among which the Sobel (1982) [52] test and bootstrapping are the best known [53]. We tested the mediation hypotheses (Hypotheses 1, 2, and 3) using an SPSS macro (developed by Preacher and Hayes, 2004) [54] that facilitates estimation of the indirect effect $a b$, both with a normal theory approach and with a bootstrap approach to obtain confidence intervals. Specifically, we chose Model 4, and then we put proactive environmental strategy into X, GHRM into M, and environmental reputation into $Y$. The control variables (financial performance and firm characteristics) were put into covariates.

\subsubsection{The Analytic Method of Moderating Effect}

For Hypothesis 4 we predicted that discretionary slack would moderate the positive relationship between proactive environmental strategy and GHRM. We also used an SPSS macro, which provided an efficient way to probe the significance of moderating effect at different values of the moderator variable. Specifically, we chose Model 1 of process, and then we put proactive environmental strategy into X, GHRM into Y, and discretionary slack into M. The control variables (financial performance and firms' property) were put into covariates.

\section{Results}

\subsection{Measurement Model Assessment}

The reliability of the constructs in this study was assessed by Cronbach's alpha. As shown in Table 1, all Cronbach's alpha values were higher than the suggested threshold value of 0.7 , indicating that the measurement for all constructs was reliable [55]. The validity of the measurement was assessed as follows. First, the measurement items were adapted from previous literature, which helped ensure content validity. Second, as shown in Table 1, all factor loading values were larger than the threshold value of 0.5 . The composite reliability values were larger than the threshold value of 0.7 . The average variance extracted (AVE) values exceed the threshold level of 0.5. These findings generally indicate convergent validity $[55,56]$. Third, as shown in Table 1 , the square root value of each construct's AVE was higher than all its correlation coefficients with other constructs, indicating that discriminant validity was adequate in this study [56].

In addition, as shown in Table 2, we examined the hypothesized measurement model with four factors (see Table 2): proactive environmental strategy, discretionary slack, green human resource management, and environmental reputation. The hypothesized four-factor model fit the data well $\left(X^{2}=661.282, \mathrm{df}=394, \mathrm{RMSEA}=0.071, \mathrm{TLI}=0.905, \mathrm{CFI}=0.914, \mathrm{SRMR}=0.053\right)$ and performed 
better than the three-factor model where financial performance and discretionary slack were combined $\left(\mathrm{X}^{2}=771.280, \mathrm{df}=397, \mathrm{RMSEA}=0.084, \mathrm{TLI}=0.867, \mathrm{CFI}=0.879, \mathrm{SRMR}=0.096\right)$, the two-factor model where financial performance, environmental reputation, and discretionary slack were combined into one factor $\left(X^{2}=1518.85, \mathrm{df}=402, \mathrm{RMSEA}=0.144, \mathrm{TLI}=0.610, \mathrm{CFI}=0.639, \mathrm{SRMR}=0.147\right)$, and the one-factor model where all items were combined into one factor $\left(X^{2}=1658.196, \mathrm{df}=405\right.$, RMSEA $=0.152, \mathrm{TLI}=0.565, \mathrm{CFI}=0.595, \mathrm{SRMR}=0.150$ ).

Table 2. Comparison of fit of alternative models.

\begin{tabular}{ccccccc}
\hline Model & $\mathbf{X}^{\mathbf{2}}$ & Df & RMSEA & TLI & CFI & SRMR \\
\hline Four-factor model & 661.282 & 394 & 0.071 & 0.905 & 0.914 & 0.053 \\
Three-factor model $^{1}$ & 771.280 & 397 & 0.084 & 0.867 & 0.879 & 0.096 \\
Two-factor model $^{2}$ & 1518.850 & 402 & 0.144 & 0.610 & 0.639 & 0.147 \\
One-factor model $^{3}$ & 1658.196 & 405 & 0.152 & 0.565 & 0.595 & 0.150 \\
\hline
\end{tabular}

Notes: ${ }^{1}$ proactive environmental strategy and discretionary slack were combined into one factor; ${ }^{2}$ proactive environmental strategy, discretionary slack, and GHRM were combined into one factor; ${ }^{3}$ all items were combined into one factor.

\subsection{Descriptive Statistics}

Table 3 shows the means, standard deviations, and intercorrelations for all variables. As seen in Table 3, proactive environmental strategy was positively related to GHRM $(b=0.353, p<0.01)$, GHRM was positively related to an increase in firm environmental reputation $(b=0.361, p<0.01)$, discretionary slack was positively related to an increase in firm environmental reputation $(b=0.325, p$ $<0.01)$, and discretionary slack was positively related to GHRM ( $b=0.462, p<0.01)$. Expressed in terms of simple association, these results were consistent with the direction of our research hypotheses, which provides preliminary evidence for our hypotheses.

Table 3. Means, standard deviations, and correlations.

\begin{tabular}{ccccccc}
\hline & PES & DS & GHRM & ER & FP & Property \\
\hline PES & 1 & & & & & \\
DS & $0.223^{* *}$ & 1 & & & & \\
GHRM & $0.353^{* *}$ & $0.462^{* *}$ & 1 & & & 1 \\
ER & $0.435^{* *}$ & $0.325^{* *}$ & $0.361^{* *}$ & 1 & 1 & 1.920 \\
FP & 0.078 & 0.046 & 0.138 & 0.142 & 0.125 & 0.535 \\
Property & 0.027 & $.221^{*}$ & 0.113 & 0.073 & 3.830 & 0.589 \\
Mean & 4.433 & 4.178 & 4.079 & 4.007 & 0.587 & \\
SD & 0.629 & 0.665 & 0.600 & & & \\
\hline
\end{tabular}

Notes: $n=131$; PES is proactive environmental strategy; GHRM is green human resource management; FP is financial performance; DS is discretionary slack; ER is environmental reputation; ${ }^{* *} p<0.05$; ${ }^{*} p<0.01$. This description also applies to Table and the Figure below.

\subsection{Tests of Mediation}

Table 4 presents the results for Hypotheses 1, 2, and 3. Supporting Hypothesis 1, proactive environmental strategy was positively associated with GHRM, as indicated by the significant model effect of proactive environmental strategy on GHRM in Model A ( $b=0.337, p<0.01)$. In support of Hypothesis 2, GHRM was found to be positively related to environmental reputation, as indicated by the significant model effect of GHRM on environmental reputation in Model B ( $b=0.218, p<0.01)$. GHRM played a mediating role in the relationship between proactive environmental strategy and environmental reputation, as indicated by the significantly indirect effect of proactive environmental strategy on environmental reputation, the indirect effect was positive (0.073) and the result did not include zero at a $95 \%$ confidence interval $(0.012,0.204)$. Furthermore, the formal two-tailed significance test demonstrated that the indirect effect was significant (Sobel $z=2.213, p<0.05$ ), thus, supporting Hypotheses 1, 2, and 3. 
Table 4. Regression results for simple mediation.

\begin{tabular}{|c|c|c|c|c|c|c|c|}
\hline \multicolumn{8}{|c|}{ Outcome: GHRM } \\
\hline Model A & $\mathrm{R}$ & R-sq & MSE & $\mathrm{F}$ & $d f_{1}$ & $d f_{2}$ & $p$ \\
\hline & 0.387 & 0.150 & 0.329 & 7.451 & 3 & 127 & 0.000 \\
\hline & coeff & se & $\mathrm{t}$ & $\mathrm{p}$ & LLCI & ULCI & \\
\hline constant & 1.989 & 0.480 & 4.142 & 0.000 & 1.039 & 2.939 & \\
\hline PES & 0.337 & 0.079 & 4.249 & 0.000 & 0.180 & 0.493 & \\
\hline FP & 0.105 & 0.085 & 1.245 & 0.215 & -0.062 & 0.272 & \\
\hline Property & 0.104 & 0.095 & 1.102 & 0.273 & -0.083 & 0.292 & \\
\hline \multicolumn{8}{|c|}{ Outcome: ER } \\
\hline \multirow[t]{3}{*}{ Model B } & $\mathrm{R}$ & R-sq & MSE & $\mathrm{F}$ & $d f_{1}$ & $d f_{2}$ & $p$ \\
\hline & 0.501 & 0.251 & 0.280 & 10.533 & 4 & 126 & 0.000 \\
\hline & coeff & se & $\mathrm{t}$ & $\mathrm{p}$ & LLCI & ULCI & \\
\hline constant & 1.258 & 0.472 & 2.666 & 0.009 & 0.324 & 2.192 & \\
\hline GHRM & 0.218 & 0.082 & 2.662 & 0.009 & 0.056 & 0.380 & \\
\hline PES & 0.334 & 0.078 & 4.280 & 0.000 & 0.180 & 0.489 & \\
\hline FP & 0.082 & 0.078 & 1.050 & 0.296 & -0.073 & 0.238 & \\
\hline Property & 0.031 & 0.088 & 0.356 & 0.722 & -0.142 & 0.205 & \\
\hline \multicolumn{8}{|c|}{ Outcome: ER (Total Effect Model) } \\
\hline Model C & $\mathrm{R}$ & R-sq & MSE & $\mathrm{F}$ & $d f_{1}$ & $d f_{2}$ & $p$ \\
\hline & 0.457 & 0.208 & 0.293 & 11.147 & 3 & 127 & 0.000 \\
\hline Model & coeff & se & $\mathrm{t}$ & $\mathrm{p}$ & LLCI & ULCI & \\
\hline constant & 1.692 & 0.454 & 3.730 & 0.000 & 0.794 & 2.589 & \\
\hline PES & 0.408 & 0.075 & 5.449 & 0.000 & 0.260 & 0.556 & \\
\hline FP & 0.105 & 0.080 & 1.319 & 0.190 & -0.053 & 0.263 & \\
\hline Property & 0.054 & 0.089 & 0.604 & 0.547 & -0.123 & 0.231 & \\
\hline \multicolumn{8}{|c|}{ Indirect Effect of $X$ on $Y$} \\
\hline & Effect & Boot SE & BootLLCI & BootULCI & & & \\
\hline GHRM & 0.073 & 0.050 & 0.012 & 0.204 & & & \\
\hline \multicolumn{8}{|c|}{ Normal Theory Tests for Indirect Effect } \\
\hline & Effect & se & $\mathrm{Z}$ & $p$ & & & \\
\hline & 0.073 & 0.033 & 2.213 & 0.027 & & & \\
\hline
\end{tabular}

\subsection{Tests of Moderating Effects}

Table 5 presents the results for Hypothesis 4, which predicted that the positive relationship between proactive environmental strategy and GHRM would be stronger for firms high on discretionary slack than for firms low on discretionary slack. Results which were significant indicated the role discretionary slack played in the relationship of proactive environmental strategy on GHRM ( $b=0.238, p<0.05)$. Values for quantitative moderators (discretionary slack) were the mean and plus/minus one standard deviation from the mean. The results indicated two of the three conditional indirect effects (based on moderator values at the mean and at one standard deviation, see Figure 2) were positive and significantly different from zero. Hypothesis 4 was supported. 
Table 5. Regression results for Moderating effect.

\begin{tabular}{cccccccc}
\hline & \multicolumn{7}{c}{ Outcome: GHRM } \\
\hline Model & $\mathrm{R}$ & $\mathrm{R}-\mathrm{sq}$ & $\mathrm{MSE}$ & $\mathrm{F}$ & $d f_{1}$ & $d f_{2}$ & $p$ \\
\hline & 0.571 & 0.326 & 0.269 & 11.819 & 5 & 122 & 0.000 \\
Model & coeff & $\mathrm{se}$ & $\mathrm{t}$ & $\mathrm{p}$ & LLCI & ULCI & \\
constant & 3.779 & 0.331 & 11.426 & 0.000 & 3.124 & 4.433 & \\
DS & 0.340 & 0.073 & 4.669 & 0.000 & 0.196 & 0.485 & \\
PES & 0.345 & 0.083 & 4.172 & 0.000 & 0.181 & 0.508 & \\
int_1 & 0.238 & 0.099 & 2.409 & 0.018 & 0.042 & 0.433 & \\
Property & -0.016 & 0.090 & -0.178 & 0.859 & -0.195 & 0.162 & \\
FP & 0.083 & 0.077 & 1.076 & 0.284 & -0.070 & 0.236 & \\
\hline
\end{tabular}

Product terms key: int_1 FES*DS

R-square Increase Due to Interaction:

\begin{tabular}{cccccc}
\hline & R2-chng & F & $d f_{1}$ & $d f_{2}$ & $p$ \\
\hline int_1 & 0.032 & 5.8025 & 1 & 122 & 0.0175 \\
\hline
\end{tabular}

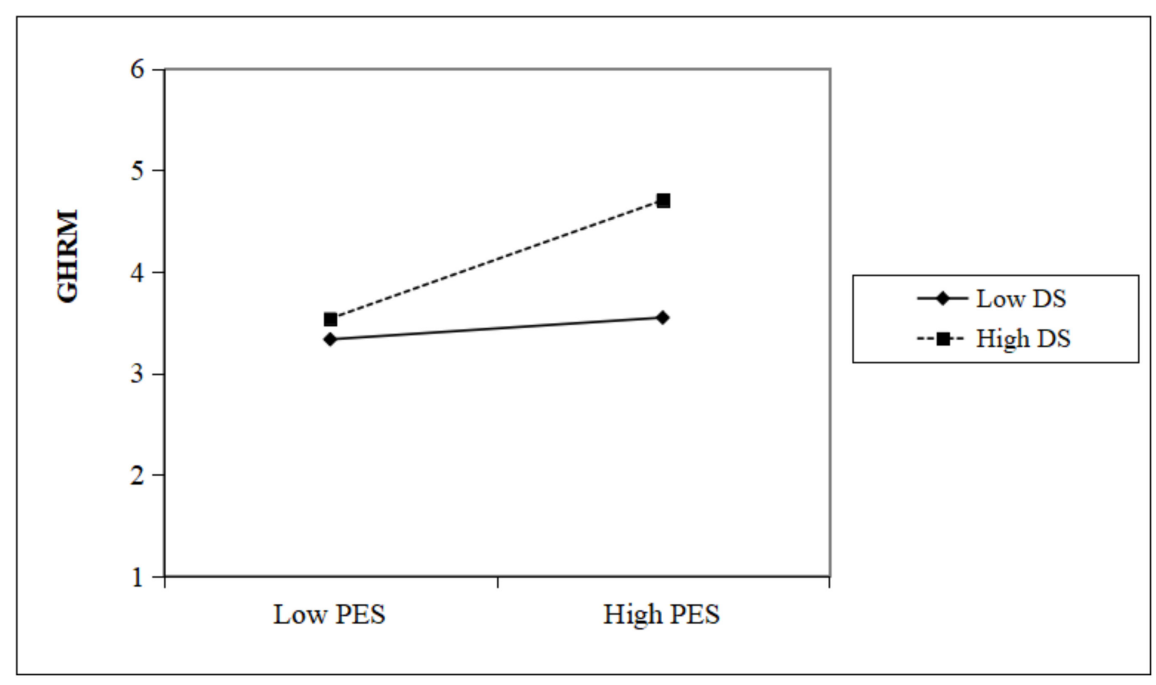

Figure 2. The moderating effect of discretionary slack.

\section{Discussion and Conclusions}

\subsection{Discussion}

Our study examined how proactive environmental strategy affects firms' environmental reputation within environmentally sensitive industries from a human resource management perspective. According to NRBV, firms need a competitive approach for implementing environmental strategy to sustain competitiveness. Prior research has not paid much attention to the roles human resources play in the process of implementing environmental strategy. However, environment management requires both leaders and employees to engage in it. In other words, it is human intensive [16]. So, GHRM, which reflects firms' environmental strategies and aims to motivate employees to participate in green activities, is an influential approach and can provide the capability for firms to effectively implement environmental strategies and gain green competitiveness [25]. Therefore, we proposed that GHRM mediates the relationship between environmental strategy and environmental reputation. We then considered if discretionary slack can amplify or attenuate the relationship between environmental strategy and GHRM. Study results supported the hypothesized moderating model, demonstrating that the magnitude of the indirect effect was contingent upon discretionary slack. Our findings 
demonstrated the presence of an important method and a boundary condition to promote the impact of proactive environmental strategy on environmental reputation.

Our results contribute to the literature by corroborating and extending prior findings in several ways. Although prior research has already demonstrated that firms' strategies and performance mainly depended on firms' resources and capabilities, little attention has been paid to how firms' environmental strategies can enhance their environmental reputation based on their green human resources, and to our knowledge, little empirical research has been found on how firms' strategies can evolve firms' abilities in green human resources. Our study enriches the NRBV and presents a more complex view of how environmental strategy facilitates environmental reputation. The results indicated that firms which tended to implement human resource management in environmental management and their managers, whose management interpretation of environmental protection is reflected by discretionary slack, seemed to be in a better position to face environmental challenges. This finding is important because it suggests that, in spite of the relationship between proactive environmental strategy and GHRM in firms, the all-important second linkage between proactive environmental strategy and GHRM is increased when managers have a better environmental awareness of using discretionary slack.

Our findings also contribute to research on slack resources and GHRM in organizations. First, discretionary slack has positive effects on helping firms face challenges. Specifically, "discretion" is an intangible resource, which is essential for facilitating the flexibility of management, and "slack" can be seen as a critical resource for firms to adjust to or address new challenges posed by radical changes in the ever-changing world. Global awareness and concerns with the risk and unpredictability of challenges posed by sustainability are drawing new attention to connections between the use of discretionary slack to facilitate proactive environmental strategies within firms. Our findings demonstrate how to make effective use of slack in promoting the influence between a firm's environmental strategy and environmental reputation. That is, slack resources are not a benefit or harm in themselves, but depend on the interpretation of managers using slack [21]. Managers can better translate slack to enhance firms' environmental management when they want to implement a green project, which provides a new perspective of investigating slack. Second, over the last three decades, issues of "sustainability" have come to figure centrally among challenges involved in the search and use of technologies, and "environmental protection" is an indispensable aspect of sustainability. So, firms in environmentally sensitive sectors face environmental challenges and put an emphasis on their environmental performance and reputation. In tandem with the roles concerned with this challenge have played in deep and far-reaching global changes in the dynamics of ecological strategies and social-ecological reputation, there has been remarkable growth of interest in research on the concept of green human resource management (GHRM). GHRM reflects a strategic orientation of firms' environmental management and is supposed to motivate all staff to improve their environmental performance and enhance their environmental reputation [57]. We demonstrated that GHRM is a necessary resource and capability for a firm to achieve its strategic goals. Our findings enrich the antecedents, boundary conditions, and outcomes of GHRM, which respond well to the call for integrating strategic human resource management and environmental sustainability [20].

In addition, our findings are consistent with NRBV [17,58,59]. According to NRBV, organizations gain competitive advantages by using their rare, valuable, inimitable, and non-substitutable resources $[6,60]$. The proactive environmental strategy is on behalf of firms' positive response to environmental problems and can help firms gain green competitiveness [50]. GHRM can cultivate high-quality, organization-specific green human capital [27,61]. Environmental reputation is regarded as a valuable, inimitable, and non-substitutable intangible asset [5]. There is no doubt that all three of them can be seen as unique resources. However, a few points are worth noting about the NRBV. It pays little attention to how organizations get access to unique resources [6] and the relationship between different unique resources has not been discussed in detail [62]. Our results demonstrate the sequence and relationship among three unique resources in a firm, which enriches NRBV. 


\subsection{Practical Implications}

Given that environmental reputation will continue to be a critical component of firms' sustainable development, our results have several implications for practice. First, our findings highlight the importance of enhancing a firm's environmental reputation on the basis of proactive environmental strategy and GHRM. Current environmental strategy is the prerequisite of a good environmental reputation, which can assist a firm in having a sustainable and competitive future in a more environmentally sensitive sector, and GHRM is an indispensable resource and capability to achieve the environmental strategy [63]. Managers, therefore, should emphasize the importance of making environmental strategy. Hesitation to invest in reducing pollution and green initiatives will prevent sustainable growth in the future. In addition, managers ought to take the necessary steps to promote the environmental protection awareness of staff via GHRM practices. Specifically, firms should take employees' environmental attitudes and capabilities into consideration when recruiting and selecting new employees (green recruitment and selection), convey firms' green thoughts, cultivate employees' green knowledge and skills when training employees (green training), establish transparent standards of green performance evaluation and improve the efficiency of firms' green performance evaluation (green performance management), set benchmarks for green compensation and rewards, as well as emphasize the importance of non-financial rewards (green pay and rewards), encourage employees to provide suggestions for firms' environmental management, and give employees autonomy to engage in environment management (green involvement). These specific GHRM practices help firms fully mobilize employees' environmental enthusiasm and create favorable conditions for enhancing their environmental performance.

Second, how to target a valuable project to enhance environmental performance is of great importance for organizations. On the one hand, our findings demonstrate that although GHRM contains uncertainty and risk because its effects may not directly bring economic benefits, it is an efficient way of contributing to firms' environmental performance. On the other hand, compared with standard human resource management practice, GHRM may need the firm to have a more stable profitability. Thus, in order to achieve green competitive and sustainable growth, firms are encouraged to invest in implementing GHRM practices, and managers should make the most of slack resources [61]. Specifically, firms should provide financial and non-financial supports to design tests and develop proper green criteria, scientific training systems, and payment for training to select and cultivate candidates who are of environmental value. Firms need to bear some losses caused by green involvement to inspire employees' green passion to gain a better environmental reputation. Managers are also expected to put the discretionary slack to "green use", which not only enables the leaders to be good environmental models in the firm, but also makes the investment in GHRM more secure [21].

\subsection{Limitations and Future Research}

Firstly, we assessed firms' environmental reputation by the evaluations of the firms' employees. Although employee ratings have unique benefits [45], different results may have been obtained for other performance measures, such as the perspective of the general public and consumers. Furthermore, we were unable to demonstrate that our perceptual measure was a totally valid predictor of "objective" environmental reputation. Future studies could use other data or other methods to include additional, more objective environmental reputation measures, which would improve confidence in the robustness of our findings.

Secondly, according to NRBV, environmental reputation is regarded as one of the most important intangible assets, has great potential to create economic value, and is not easy to replicate $[5,64]$. Little research has focused on how to cultivate reputation, especially from the human resource management perspective. Although we took environmental reputation as the outcome or performance of environmental strategy and proposed that GHRM is a specific capability and resource to support the implementation of proactive environmental strategy and enhance firms' environmental reputation [20], there might be other positive outcomes of a firm's environmental strategy, such as innovative 
performance at the organizational level, and employee green behavior and green creativity at the individual level. Future research can further explore the outcomes of environmental strategy via GHRM.

Thirdly, our research was not exhaustive in considering all possible moderating variables. We focused on the discretionary slack for managers in using environmentally friendly initiatives, which reflects managerial interpretation about environmental management, but there are other forms of responses, such as leadership (e.g., ethical leadership), that need investigation. In addition, our article mainly focused on Chinese firms, and there might be cultural difference between different countries, which may cause differences in the choice of environmental strategy and the implementation of GHRM. So, a cross-cultural study of these topics can be further explored in the future.

Author Contributions: Conceptualization, Data collection and draft writing of some parts of the manuscript, J.Z.; Data curation, analysis and method part writing, W.S.; Introduction and hypotheses parts writing, H.L.; Funding acquisition, J.Z.; Investigation, J.Z.; Methodology, W.S.; Writing-Original draft, J.Z. and H.L.; Writing一Review and editing, J.Z., H.L. and W.S.. All authors have read and agreed to the published version of the manuscript.

Funding: This research was funded by National Natural Science Foundation of China (71872102).

Conflicts of Interest: The authors declare no conflict of interest.

\section{References}

1. Barney, J. Firm resources and sustained competitive advantage. J. Manag. 1991, 17, 99-120. [CrossRef]

2. Walker, K. A systematic review of the corporate reputation literature: Definition, measurement, and theory. Corp. Reput. Rev. 2010, 12, 357-387. [CrossRef]

3. Sharfman, M.P.; Fernando, C.S. Environmental risk management and the cost of capital. Strateg. Manag. J. 2008, 29, 569-592. [CrossRef]

4. Castilla-Polo, F.; Gallardo-Vázquez, D.; Sánchez-Hernández, M.I.; Rodríguez, M.C.R. An empirical approach to analyze the reputation-performance linkage in agrifood cooperatives. J. Clean. Prod. 2018, 195, 163-175. [CrossRef]

5. Russo, M.V.; Fouts, P.A. A resource-based perspective on corporate environmental performance and profitability. Acad. Manag. J. 1997, 40, 534-559.

6. Barney, J.B.; Clark, D.N. Resource-Based Theory: Creating and Sustaining Competitive Advantage; Oxford University Press: NY, USA, 2007.

7. Dai, J.; Cantor, D.E.; Montabon, F.L. Examining corporate environmental proactivity and operational performance: A strategy-structure-capabilities-performance perspective within a green context. Int. J. Prod. Econ. 2017, 193, 272-280. [CrossRef]

8. Hart, S.L. A natural-resource-based view of the firm. Acad. Manag. Rev. 1995, 20, 986-1014. [CrossRef]

9. Sharma, S. Managerial interpretations and organizational context as predictors of corporate choice of environmental strategy. Acad. Manag. J. 2000, 43, 681-697.

10. Peng, B.; Tu, Y.; Elahi, E.; Wei, G. Extended Producer Responsibility and corporate performance: Effects of environmental regulation and environmental strategy. J. Environ. Manag. 2018, 218, 181-189. [CrossRef]

11. Duque-Grisales, E.; Aguilera-Caracuel, J.; Guerrero-Villegas, J.; García-Sánchez, E. Can proactive environmental strategy improve Multilatinas' level of internationalization? The moderating role of board independence. Bus. Strategy Environ. 2019. [CrossRef]

12. Danso, A.; Adomako, S.; Amankwah-Amoah, J.; Owusu-Agyei, S.; Konadu, R. Environmental sustainability orientation, competitive strategy and financial performance. Bus. Strategy Environ. 2019, 28, 885-895. [CrossRef]

13. Feng, T.; Zhao, G.; Su, K. The fit between environmental management systems and organisational learning orientation. Int. J. Prod. Res. 2014, 52, 2901-2914. [CrossRef]

14. Ateş, M.A.; Bloemhof, J.; Van Raaij, E.M.; Wynstra, F. Proactive environmental strategy in a supply chain context: The mediating role of investments. Int. J. Prod. Res. 2012, 50, 1079-1095. [CrossRef]

15. Tsai, K.H.; Liao, Y.C. Sustainability strategy and eco-innovation: A moderation model. Bus. Strategy Environ. 2017, 26, 426-437. [CrossRef]

16. Zhang, S.; Wang, Z.; Zhao, X. Effects of proactive environmental strategy on environmental performance: Mediation and moderation analyses. J. Clean. Prod. 2019, 235, 1438-1449. [CrossRef] 
17. Ren, S.; Tang, G.; Jackson, S.E. Green human resource management research in emergence: A review and future directions. Asia Pac. J. Manag. 2018, 35, 769-803. [CrossRef]

18. Sharma, S.; Vredenburg, H. Proactive corporate environmental strategy and the development of competitively valuable organizational capabilities. Strateg. Manag. J. 1998, 19, 729-753. [CrossRef]

19. Marquis, C.; Jackson, S.E.; Li, Y. Building sustainable organizations in China. Manag. Organ. Rev. 2015, 11, 427-440. [CrossRef]

20. Tang, G.; Chen, Y.; Jiang, Y.; Paillé, P.; Jia, J. Green human resource management practices: Scale development and validity. Asia Pac. J. Hum. Resour. 2018, 56, 31-55. [CrossRef]

21. Wiersma, E. How and when do firms translate slack into better performance? Br. Account. Rev. 2017, 49, 445-459. [CrossRef]

22. Aragón-Correa, J.A.; Sharma, S. A contingent resource-based view of proactive corporate environmental strategy. Acad. Manag. Rev. 2003, 28,71-88. [CrossRef]

23. Li, H.; Kwaku, A. Product innovation strategy and the performance of new technology ventures in China. Acad. Manag. J. 2001, 44, 1123-1134.

24. Chen, Y.J.; Wu, Y.J.; Wu, T. Moderating effect of environmental supply chain collaboration: Evidence from Taiwan. Int. J. Phys. Distrib. Logist. Manag. 2015, 45, 959-978. [CrossRef]

25. Daily, B.F.; Huang, S.C. Achieving sustainability through attention to human resource factors in environmental management. Int. J. Oper. Prod. Manag. 2001, 21, 1539-1552. [CrossRef]

26. Bos-Nehles, A.; Renkema, M.; Janssen, M. HRM and innovative work behaviour: A systematic literature review. Pers. Rev. 2017, 46, 1228-1253. [CrossRef]

27. Jiang, K.; Lepak, D.P.; Hu, J.; Baer, J.C. How does human resource management influence organizational outcomes? A meta-analytic investigation of mediating mechanisms. Acad. Manag. J. 2012, 55, 1264-1294. [CrossRef]

28. Boselie, P.; Dietz, G.; Boon, C. Commonalities and contradictions in HRM and performance research. Hum. Resour. Manag. J. 2005, 15, 67-94. [CrossRef]

29. Antonioli, D.; Mancinelli, S.; Mazzanti, M. Is environmental innovation embedded within high-performance organisational changes? The role of human resource management and complementarity in green business strategies. Res. Policy 2013, 42, 975-988. [CrossRef]

30. Del Brío, J.Á.; Fernandez, E.; Junquera, B. Management and employee involvement in achieving an environmental action-based competitive advantage: An empirical study. Int. J. Hum. Resour. Manag. 2007, 18, 491-522. [CrossRef]

31. Jabbour, C.J.C.; De Sousa Jabbour, A.B.L. Green human resource management and green supply chain management: Linking two emerging agendas. J. Clean. Prod. 2016, 112, 1824-1833. [CrossRef]

32. Renwick, D.; Redman, T.; Maguire, S. Green human resource management: A review and research agenda. Int. J. Manag. Rev. 2013, 15, 1-14. [CrossRef]

33. Fleischer, D. Green Teams: Engaging Employees in Sustainability. In Green Biz Reports; Mill Vammey: CA, USA, 2009.

34. Dangelico, R.M.; Pontrandolfo, P. Being 'green and competitive': The impact of environmental actions and collaborations on firm performance. Bus. Strategy Environ. 2015, 24, 413-430. [CrossRef]

35. Li, J.; Huang, J.; Liu, Z.; Cai, Z. The effects of employee training on the relationship between environmental attitude and firms performance in sustainable development. Int. J. Hum. Resour. Manag. 2011, 23, 1-14.

36. Wagner, A. The Origins of Evolutionary Innovations: A Theory of Transformative Change in Living Systems; OUP: Oxford, UK, 2011.

37. George, G. Slack resources and the performance of privately held firms. Acad. Manag. J. 2005, 48, 661-676. [CrossRef]

38. Cyert, R.M.; March, J.G. A Behavioral Theory of the Firm; Englewood Cliffs: NJ, USA, 1963; Volume 2, pp. 169-187.

39. Mousa, F.T.; Chowdhury, J. Organizational slack effects on innovation: The moderating roles of CEO tenure and compensation. J. Bus. Econ. Manag. 2014, 15, 369-383. [CrossRef]

40. Podsakoff, P.M.; MacKenzie, S.B.; Lee, J.Y.; Podsakoff, N.P. Common method biases in behavioral research: A critical review of the literature and recommended remedies. J. Appl. Psychol. 2003, 88, 879-903. [CrossRef]

41. Brislin, R.W. Back-translation for cross-cultural research. J. Cross Cult. Psychol. 1970, 1, 185-216. [CrossRef] 
42. Backhaus, K.; Tikoo, S. Conceptualizing and researching employer branding. Career Dev. Int. 2004, 9, 501-517. [CrossRef]

43. Helm, S. Employees' awareness of their impact on corporate reputation. J. Bus. Res. 2011, 64, 657-663. [CrossRef]

44. Dixon-Fowler, H.; O'Leary-Kelly, A.; Johnson, J.; Waite, M. Sustainabilty and ideology-infused psychological contracts: An organizational-and employee-level perspective. Hum. Resour. Manag. Rev. 2019. [CrossRef]

45. Zheng, X.; Cheng, D.D. Corporate Reputation Measurement Based on Employee Perspective. In DEStech Transactions on Social Science, Education and Human Science, Proceedings of the 4th International Conference on Social Science, Wuhan, China, 15-17 December 2017; DEStech Publications, Inc.: Lancaster, PA, USA, 2017.

46. Buttner, E.H. Entrepreneurial stress: Is it hazardous to your health? J. Manag. Issues 1992, 4, 223-240.

47. Pollack, J.M.; Vanepps, E.M.; Hayes, A.F. The moderating role of social ties on entrepreneurs' depressed affect and withdrawal intentions in response to economic stress. J. Appl. Psychol. 2012, 98, 789-810. [CrossRef]

48. Aiken, L.S.; West, S.G.; Reno, R.R. Multiple Regression: Testing and Interpreting Interactions; SAGE: Thousand Oaks, CA, USA, 1991.

49. Baron, R.M.; Kenny, D.A. The moderator-mediator variable distinction in social psychological research: Conceptual, strategic, and statistical considerations. J. Pers. Soc. Psychol. 1986, 51, 1173-1182. [CrossRef] [PubMed]

50. MacKinnon, D.P.; Lockwood, C.M.; Hoffman, J.M.; West, S.G.; Sheets, V. A comparison of methods to test mediation and other intervening variable effects. Psychol. Methods 2002, 7, 83-104. [CrossRef]

51. Shrout, P.E.; Bolger, N. Mediation in experimental and nonexperimental studies: New procedures and recommendations. Psychol. Methods 2002, 7, 422-445. [CrossRef]

52. Sobel, M.E. Asymptotic confidence intervals for indirect effects in structural equation models. Sociol. Methodol. 1982, 13, 290-312. [CrossRef]

53. Cole, M.S.; Walter, F.; Bruch, H. Affective mechanisms linking dysfunctional behavior to performance in work teams: A moderated mediation study. J. Appl. Psychol. 2008, 93, 945-958. [CrossRef]

54. Preacher, K.J.; Hayes, A.F. SPSS and SAS procedures for estimating indirect effects in simple mediation models. Behav. Res. Methods Instrum. Comput. 2004, 36, 717-731. [CrossRef]

55. Nunnally, J.; Bernstein, I. Psychometric Theory, 3rd ed.; MacGraw-Hill: New York, NY, USA, 1994.

56. Fornell, C.; Larcker, D.F. Structural Equation Models with Unobservable Variables and Measurement Error: Algebra and Statistics. J. Mark. Res. 1981, 18, 328-388. [CrossRef]

57. Guerci, M.; Pedrini, M. The consensus between Italian HR and sustainability managers on HR management for sustainability-driven change-towards a 'strong' HR management system. Int. J. Hum. Resour. Manag. 2014, 25, 1787-1814. [CrossRef]

58. Wright, P.M.; McMahan, G.C.; McWilliams, A. Human resources and sustained competitive advantage: A resource-based perspective. Int. J. Hum. Resour. Manag. 1994, 5, 301-326. [CrossRef]

59. Ployhart, R.E.; Moliterno, T.P. Emergence of the human capital resource: A multilevel model. Acad. Manag. Rev. 2011, 36, 127-150. [CrossRef]

60. Wernerfelt, B. A resource-based view of the firm. Strateg. Manag. J. 1984, 5, 171-180. [CrossRef]

61. Jia, J.; Liu, H.; Chin, T.; Hu, D. The continuous mediating effects of GHRM on employees' green passion via transformational leadership and green creativity. Sustainability 2018, 10, 3237. [CrossRef]

62. Kraaijenbrink, J.; Spender, J.C.; Groen, A.J. The resource-based view: A review and assessment of its critiques. J. Manag. 2010, 36, 349-372. [CrossRef]

63. Roberts, P.W.; Dowling, G.R. Corporate reputation and sustained superior financial performance. Strateg. Manag. J. 2002, 23, 1077-1093. [CrossRef]

64. Grund, N.E. Reputation: Realizing value from the corporate image. Acad. Manag. Exec. 1996, 10, 99-101.

(C) 2020 by the authors. Licensee MDPI, Basel, Switzerland. This article is an open access article distributed under the terms and conditions of the Creative Commons Attribution (CC BY) license (http://creativecommons.org/licenses/by/4.0/). 